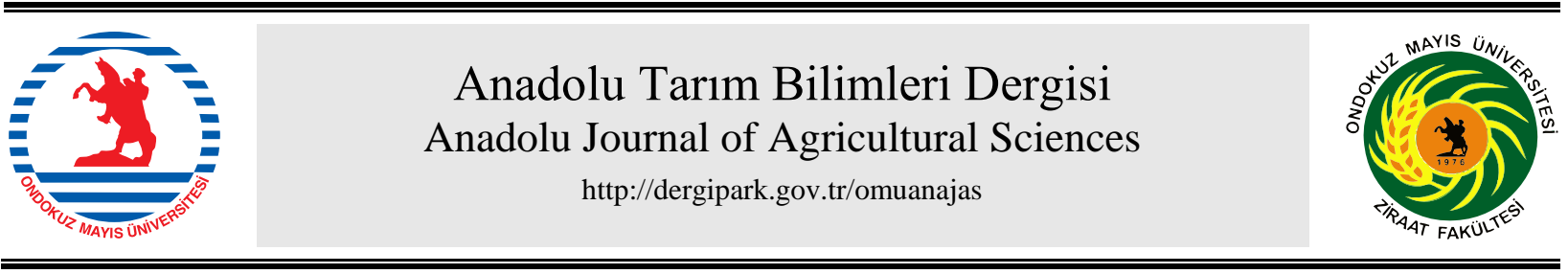

\title{
Araştırma/Research
}

Anadolu Tarım Bilim. Derg./Anadolu J Agr Sci, 34 (2019) ISSN: 1308-8750 (Print) 1308-8769 (Online) doi: 10.7161/omuanajas.531137

\section{Sodyum diasetat ilavesinin yonca silajlarının fermantasyon özellikleri, kimyasal kompozisyonu ve aerobik stabilitesi üzerine etkisi}

\author{
Fatma Hışman Akça, Mehmet Levent Özdüven, Fisun Koç* \\ Tekirdă̆ Namık Kemal Üniversitesi Ziraat Fakültesi Zootekni Bölümü \\ *Sorumlu yazar/corresponding author: fkoc@nku.edu.tr
}

Geliş/Received 22/02/2019 Kabul/Accepted 29/07/2019

\begin{abstract}
ÖZET
$\mathrm{Bu}$ araștırma, sodyum diasetat (SDA) kullanımının yonca silajlarında fermantasyon özellikleri, kimyasal kompozisyonu ve aerobik stabilitesi üzerindeki etkisini belirlemek amacıyla yürütülmüştür. Araştırmada kullanılan yonca (Medicago sativa L.) çiçeklenme döneminde hasat edilmiş ve yaklaşık 1.5-2.0 cm boyutunda parçalanan taze materyale 0 (kontrol), 3.0, 5.0 ve $7.0 \mathrm{~g} \mathrm{~kg}^{-1} \mathrm{KM}_{\text {düzeyinde }}$ SDA katılmıştır. Katkı maddesi ilavesinden sonra, yaklaşık $500 \mathrm{~g}$ yonca plastik torbalara koyularak sıkıştırılmış ve vakumla içindeki hava alınmıştır. Her muameleye ait 10'ar paket silajın kullanıldığ çalışmada, silajların paketlenmesinden sonra materyaller laboratuvar koşullarında $\left(25-30{ }^{\circ} \mathrm{C}\right)$ depolanmıştır. Silolamadan 45 gün sonra açılan tüm silajlarda kimyasal ve mikrobiyolojik analizler yapılmıştır. Silolama döneminin sonunda (45. gün) tüm silajlara 7 gün süre ile aerobik stabilite testi uygulanmıştır. Araştırmada ayrıca fermantasyonun 45. günü ve aerobik stabilite dönemi sonrası baskın olan laktik asit bakteri türleri tespit edilmiştir. Sonuç olarak, yonca silajına ilave edilen SDA silajların laktik ve asetik asit içeriklerini artırırken, proteolizi de önlemiştir. Ayrıca, SDA yüksek anti bakteriyel aktivite göstererek silajların 7 günlük aerobik dönem boyunca maya ve küf populasyonları ile $\mathrm{CO}_{2}$ üretimlerini düşürmüş ve aerobik stabilitelerini geliştirmiştir.
\end{abstract}

The effects of sodium diacetate addition on the fermentation characteristics, chemical composition and aerobic stability of alfalfa silages

\section{ABSTRACT}

The objective of this study was to evaluate the effect of sodium diacetate (SDA) on fermentation characteristics, chemical composition and aerobic stability of alfalfa (Medicago sativa L.) silage. SDA was applied at 0 (control), 3.0, 5.0 and $7.0 \mathrm{~g} \mathrm{~kg}^{-1} \mathrm{DM}$ levels to alfalfa forage harvested at flowering stage and chopped to about $1.5-2.0 \mathrm{~cm}$ length. After the addition of the additives, approximately $500 \mathrm{~g}$ of sample was placed in plastic bag sample was placed in plastic bags and compressed. After packing, 10 sample packets from each treatment were stored under laboratory conditions $\left(25-30{ }^{\circ} \mathrm{C}\right)$. The aerobic stability test was applied to the silages opened on the 45 day for 7 days. Aerobic stability characteristics were monitored during 7 days after the main fermentation periods. In addition, lactic acid bacteria which are dominant after $45^{\text {th }}$ day of fermentation and aerobic stability period were determined. As a result, SDA that applied to alfalfa decreased lactic and acetic acid concentrations and prevented proteolysis in the silages. However, SDA showed a high antibacterial activity in alfalfa. During the 7 days aerobic period, sodium diasetate increased $\mathrm{pH}$ values, yeast and moulds populations and production of $\mathrm{CO}_{2}$ and improved aerobic stability of alfalfa silage.

\section{Giriş}

Yaygın olarak ruminant ve diğer hayvanların beslenmesinde kullanılmakta olan baklagil yem bitkileri arasında yer alan yonca (Medicago sativa) daha çok kuru ot formunda hayvanlara verilmektedir (Çerçi ve ark., 1996). Ancak kurutulmasi ve depolanmasi sırasında yapılan mekanik müdahaleler, önemli ölçüde
Anahtar Sözcükler: Aerobik stabilite Laktik asit bakterileri Sodyum diasetat Yonca silaj 1

Keywords: Aerobic stability Lactic acid bacteria Sodium diacetate Alfalfa silage

C OMU ANAJAS 2019

besin madde kaybının meydana gelmesine neden olmaktadır (Çiftçi ve ark., 2005). Son y1llarda, yonca bitkisinin kuru ot olarak değerlendirilmesinin yanı sıra silaj yapımı da önem kazanmıştır. Özellikle kurutma imkanı olmayan, bol yağışı alan bölgelerde son biçim yoncalar genellikle silaj olarak değerlendirilmektedir (Çerçi ve ark., 1996). Silaj olarak yonca; protein ve mineral madde düzeyinin yüksek olması, suda 
çözünebilir karbonhidratlar (SÇK) içeriğinin düşük olması ve tampon kapasitesinin (Tk) yüksekliği ile silolanması güç yemler sınıfına girmektedir (Kılıç, 1986). Bu tür yemlerden kaliteli silajlar elde etmek oldukça güçtür. Bu nedenle, protein bakımından zengin, karbonhidrat bakımından fakir olan bu tür silajlık yem bitkilerinin silolanması sirasinda fermantasyonun güvence altına alınabilmesi için katkı maddelerinin kullanılması zorunlu hale gelmektedir (Kılıç, 1986; Güler, 2001). Silaj fermantasyonunda katk1 maddeleri kullanımı yaygın bir uygulama olup bu amaçla kullanılan çok sayıda biyolojik ve kimyasal kökenli ürün bulunmaktadır. Söz konusu ürünler genel olarak fermantasyon etkinliği ve aerobik stabiliteyi geliştirmek, hijyenik riskleri en aza indirmek için kullanılırlar (Altınçekiç ve Filya, 2018).

Organik asitler ve tuzları, yemlerde küf gelişimini önlemek, yem ve yem hammaddelerinin depolama sürelerini arttırmak, sindirim ve emilime yardımc1 olmak amacıyla kullanılmaktadır. Doğada saf halde bulunan veya fermantasyon sonucu açığa çıkan organik asitler; laktik, sitrik ve malik asit gibi her birinin molekül yapısında karboksil grubu $(-\mathrm{COOH})$ bulunan yağ asitleri ile Ca-format, Ca-propiyonat gibi tuz formlarından oluşan bileşiklerdir (İpçak ve ark., 2017). Silajların organik asit ilavesi yoluyla doğrudan asitleştirilmesi $\mathrm{pH}$ 'da ani düşüşe ve istenmeyen bakterilerin gelişiminde inhibisyona yol açar ve bu da besin madde kaybının azalmasına neden olur. Ancak, organik asitlerin kullanımındaki dezavantajlardan biri, keskin ve rahatsız edici kokularının olmasıdır. $\mathrm{Bu}$ nedenle alternatif silaj katk1 maddeleri olarak daha güvenli olan organik asit tuzları önerilmektedir. Bir asetat türevi ve gıda koruyucu olan sodyum diasetat (SDA) bileşiminde (sodyum asetat ve asetik asit) içerir. Enterobakteri ve mayaların büyümesinin engellenmesi için etkili maddeler olduğu kanıtlanmış olan SDA etkili bir mikrobiyal inhibitördür ve silajların yemleme dönemini uzatmak için antibakteriyel ajan olarak kullanılmaktadır (Yuan ve ark., 2017).

$\mathrm{Bu}$ çalışmanın amacı, yonca silajına farklı dozlarda SDA ilavesinin silaj fermantasyonu ve aerobik stabilite üzerine etkisini ortaya koymaktır.

\section{Materyal ve Yöntem}

\subsection{Silajların hazırlanması}

$\mathrm{Bu}$ araştırmada silaj materyali olarak Namık Kemal Üniversitesi Ziraat Fakültesi Araştırma ve Uygulama Merkezinde yetiştirilen yonca (Medicago sativa) bitkisi kullanılmışır. Silajı yapılacak yonca hasılları çiçeklenme başlangıcında (yaklaşık \% 10 çiçeklenme) hasat edilmiştir.

Hasat edilerek 24 saat süreyle soldurulan yonca, silaj makinesiyle yaklaşı $1.5-2.0 \quad \mathrm{~cm}$ boyutlarında parçalanmıştır. Çalışmada katkı maddesi olarak Kimbiotek firmasından temin edilen bileşiminde (asetat ve asetik asit içeren) (ALFASOL E262) kullanılmıştır.
Araştırma, katkı maddesi ilave edilmeyen kontrol, S3: $3 \mathrm{~g} \mathrm{~kg}^{-1}$ SDA, S5: $5 \mathrm{~g} \mathrm{~kg}^{-1}$ SDA ve S7: $7 \mathrm{~g} \mathrm{~kg}^{-1}$ SDA ilave edilerek oluşturulan 4 grupta yürütülmüştür. Kontrol grubuna diğer muamele gruplarına eşdeğer 20 $\mathrm{ml}$ çeşme suyu ilave edilmiştir. Katkı maddelerinin ilavesinden sonra, yaklaşık $500 \mathrm{~g}$ yem örneği plastik torbalara koyularak sıkıştırılmış ve vakumla içindeki hava alınmıştır. Her grup için 10'ar tane olmak üzere toplam 40 paket silaj laboratuvar şartlarında $\left(25-30^{\circ} \mathrm{C}\right)$ 45 gün fermantasyona bırakılmışıır. Kırk beşinci gün açılan silajlara 7 gün süre ile aerobik stabilite testi uygulanmıştır.

\subsection{Kimyasal analizler}

Fermantasyonun 45. gününde açılan silajlarda $\mathrm{pH}$, kuru madde (KM), laktik asit (LA), asetik asit (AA), bütirik asit (BA), propiyonik asit (PA) suda çözünebilir karbonhidratlar (SÇK), amonyağa bağlı nitrojen $\left(\mathrm{NH}_{3}{ }^{-}\right.$ $\mathrm{N}$ ), mikrobiyolojik kompozisyona ilişkin olarak laktik asit bakterileri (LAB), maya ve küf sayımları yapılmıştır. Araştırmada $\mathrm{pH}$ ve Tk analizleri Playne ve McDonald (1966), KM analizi Akyıldız (1984), $\mathrm{NH}_{3}-\mathrm{N}$ ve SÇK analizleri Anonim (1986), LA analizi Koç ve Coşkuntuna (2003)'nın bildirdiği spektrofotometrik yöntem ile saptanmıştır. AA, BA ve PA analizi ise Supelco (1998) tarafindan bildirilen yönteme göre gaz kromatografisi (GC-15A, Shimadzu, Japonya) ile yapılmıştır. Silajların kuru madde kayıpları, 45. günlerde torbalarında hesaplanan silaj KM'si ağırlığının, torbalara konulan taze materyalin $\mathrm{KM}$ ağırlığına oranlanması ile hesap edilmiştir (Kleinschmit ve ark., 2005). Silajların KM ve $\mathrm{pH}$ değerleri belirlenerek Flieg puanları hesaplanmıştır (Kılıç, 1986).

Flieg Puanı $=220+(2 \times \%$ silo yemi KM'si-15) $-40 \mathrm{x}$ silo yemi pH içeriği

\subsection{Mikrobiyolojik analizler}

Laktik asit bakterileri, maya ve küf yoğunluğunun belirlenmesinde Seale ve ark. (1990)'nın önerdiği yöntem takip edilmiştir.

\subsection{S rRNA Dizi Analizleri}

Tür ayrımı RAPD-PCR analizi ile $25 \mu$ reaksiyon solüsyonunda yapılmış ve primer olarak M13 (5'GAGGGTGGCGGTTCT3') primeri kullanılmıştır (Settani ve ark., 2011). M13 primeri kullanılarak yapılan PCR reaksiyonu Zapparoli ve ark. (1998)'nın yöntemi modifiye edilerek yapılmıştır. Amplifikasyon işlemi sırasında kullanılan PCR programı; $94{ }^{\circ} \mathrm{C}$ ' de $2 \mathrm{dk}$ başlangıç denatürasyon aşaması, 40 döngüden oluşan 94 ${ }^{\circ} \mathrm{C}^{\prime} \mathrm{de} 1 \mathrm{dk}$ denatürasyon, $42{ }^{\circ} \mathrm{C}$ 'de 20 sn bağlanma ve $72{ }^{\circ} \mathrm{C}$ 'de $2 \mathrm{dk}$ uzama aşamasından oluşmaktadır. RAPD-PCR işleminden sonra çoğaltılan DNA bölgeleri agaroz jel elektroforezinden faydalanılarak boyutlarına göre gruplara ayrılmışıtır ve her grubu temsilen 1 veya 2 örnekte 16S rRNA bölgesi sekanslanmıştır. 
16S rRNA bölge çoğaltımı yapılmıştır. 16S rRNA dizi bölgeleri, rD1 ve (5' AAGGAGGTGATCCAGCC 3') ve fD1 (5' AGAGTTTGATCCTGGCT 3') primerleri kullanılarak PCR' da çoğaltılmıştır. Toplam reaksiyon hacmi $50 \mu$ l olacak şekilde tüplere steril distile su, DNA $(1 \mu \mathrm{l}), 20 \mathrm{mM} \mathrm{MgCl} 2$ içeren tampon (3 $\mu \mathrm{l})$, dNTP $(0.3 \mu \mathrm{l})$, Primer rD1 $(0.06 \mu \mathrm{l})$, Primer fD1 $(0.06 \mu \mathrm{l})$ ve Taq $(0.3 \mu \mathrm{l})$ konmuştur.

Amplifikasyon işlemi sırasında kullanılan PCR programı; $95{ }^{\circ} \mathrm{C}$ 'de $3 \mathrm{dk}$ başlangıç denatürasyon aşamas1, 30 döngüden oluşan $94{ }^{\circ} \mathrm{C}^{\prime} \mathrm{de} \quad 1 \mathrm{dk}$ denatürasyon, $54{ }^{\circ} \mathrm{C}$ 'de 45 sn bağlanma ve $72{ }^{\circ} \mathrm{C}$ 'de 2 dk uzama aşamasından oluşmaktadır.

Elde edilen PCR ürünleri, $1 \mathrm{X}$ TBE tamponu ile hazırlanmış ve SYBR Safe DNA Gel (INVITROGEN) eklenmiş \% $1.5\left(\mathrm{w} \mathrm{v}^{-1}\right)^{\prime}$ lik agaroz jelinde elektroforez işlemine tabi tutulmuştur. Elektroforez işleminden sonra jel, "Kodak EDAS 290" marka UV Transilluminatör altında görüntülenmiş ve DNA bantları analiz edilmiştir. DNA bantlarının boyutlarını hesaplamada standart olarak 100 baz çiftlik DNA marker (Fermentas) kullanılmıştır.

Baz sirasi belirlendikten sonra, bu sira (http://www.ncbi.nlm .nih.gov./BLAST/) adlı internet sayfasinda bulunan program kullanılarak veri tabanı ile karşılaştırılmıştır. Tarama sonucu, aranan dizi sırasının hangi mikroorganizmaya ait olabileceği, benzerlik yüzdesi ile birlikte belirlenmiştir (Boyacı Gündüz, 2018).

\subsection{Aerobik stabilite}

Kırk beş günlük silolama süresi sonunda silaj örneklerine 7. gün sonunda Ashbell ve ark. (1991) tarafından önerilen yönteme göre aşınmaya dirençli gaz sızdırmaz özellikteki polietilen şişelerden hazırlanan düzeneğin kullanıldığ 1 aerobik stabilite testi uygulanmıştır. Silajlardaki görsel küflenmenin saptanmasinda ise Filya ve ark. (2000) tarafindan geliştirilen değerlendirme yöntemi kullanılmıştır.

\subsection{Istatistiksel analizler}

Araştırma sonunda elde edilen veriler SPSS v.16 istatistik paket programının (SPSS Inc. 2007) GLM prosedüründe değerlendirilmiştir. Grup ortalamaları arasındaki farklılıkların karşıllaştırılmasında Duncan testi kullanılmıştır (Efe ve ark., 2000).

\section{Bulgular ve Tartışma}

\subsection{Silajların fermantasyon özelllikleri}

Taze yoncaya ait kimyasal ve mikrobiyolojik analiz sonuçları Çizelge 1 ve Çizelge 2'de verilmiştir.

Yonca bitkisinin $\mathrm{pH}$, Tk değeri, KM içindeki HP ve SÇK, LAB ve maya içerikleri sırasıyla $7.80,478 \mathrm{mEq}$ $\mathrm{kg}^{-1} \mathrm{KM}, \% 20.21,15.45 \mathrm{~g} \mathrm{~kg}^{-1} \mathrm{KM}, 5.35,8.00 \log _{10}$ kob $\mathrm{g}^{-1}$ arasında bulunmuştur. Yonca silajlarında başlangıç materyaline ilişkin veriler, bu konudaki çalışmalarla benzerlik göstermektedir (Yuan ve ark., 2016; Wen ve ark., 2017; Yuan ve ark., 2017).

Çizelge 1. Taze ve yonca silajlarının kimyasal analiz sonuçları

\begin{tabular}{|c|c|c|c|c|c|c|}
\hline \multirow{2}{*}{ Özellikler } & \multicolumn{5}{|c|}{ Muameleler } & \multirow[b]{2}{*}{$P$} \\
\hline & TM & Kontrol & SD3 & SD5 & SD7 & \\
\hline $\begin{array}{l}\text { Tk, meq } \mathrm{NaOH} \\
\mathrm{kg} \mathrm{KM}^{-1}\end{array}$ & 478 & - & - & - & - & \\
\hline $\mathrm{pH}$ & 7.80 & $5.80 \pm 0.10^{\mathrm{a}}$ & $5.75 \pm 0.15^{\mathrm{a}}$ & $5.60 \pm 0.00^{\mathrm{a}}$ & $5.35 \pm 0.15^{\mathrm{b}}$ & $<0.01$ \\
\hline $\mathrm{KM} \% \mathrm{TM}$ & 31.08 & $28.04 \pm 1.30^{\mathrm{c}}$ & $28.45 \pm 0.57^{\mathrm{bc}}$ & $29.72 \pm 0.35^{\mathrm{ab}}$ & $29.98 \pm 0.18^{\mathrm{a}}$ & $<0.05$ \\
\hline $\mathrm{HP}, \% \mathrm{KM}$ & 20.21 & $19.72 \pm 0.10^{\mathrm{c}}$ & $19.80 \pm 0.01^{\mathrm{bc}}$ & $19.92 \pm 0.09^{b}$ & $20.28 \pm 0.01^{\mathrm{a}}$ & $<0.001$ \\
\hline $\mathrm{SÇK}, \mathrm{g} \mathrm{kg}^{-1} \mathrm{KM}$ & 15.45 & $9.96 \pm 1.01$ & $8.72 \pm 2.70$ & $8.00 \pm 0.29$ & $6.60 \pm 0.53$ & Ö.D \\
\hline $\mathrm{NH}_{3}-\mathrm{N}, \mathrm{g} \mathrm{kg}^{-1} \mathrm{KM}$ & - & $4.51 \pm 0.21^{\mathrm{a}}$ & $4.27 \pm 0.02^{\mathrm{a}}$ & $3.95 \pm 0.08^{\mathrm{a}}$ & $2.94 \pm 0.74^{\mathrm{b}}$ & $<0.005$ \\
\hline $\mathrm{NH}_{3}-\mathrm{N} / \mathrm{TN}, \mathrm{g} \mathrm{kg}^{-1} \mathrm{KM}$ & - & $142.16 \pm 6.60^{a}$ & $133.97 \pm 1.26^{\mathrm{b}}$ & $125.20 \pm 3.06^{\mathrm{c}}$ & $111.98 \pm 1.29^{\mathrm{d}}$ & $<0.001$ \\
\hline $\mathrm{LA}, \mathrm{g} \mathrm{kg}^{-1} \mathrm{KM}$ & 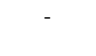 & $6.77 \pm 1.43^{\mathrm{c}}$ & $26.56 \pm 1.82^{b}$ & $64.96 \pm 1.54^{\mathrm{a}}$ & $70.04 \pm 7.88^{\mathrm{a}}$ & $<0.001$ \\
\hline $\mathrm{BA}, \mathrm{g} \mathrm{kg}^{-1} \mathrm{KM}$ & - & $1.92 \pm 0.46^{\mathrm{a}}$ & $1.90 \pm 4.09^{\mathrm{a}}$ & $1.48 \pm 3.71^{\mathrm{ab}}$ & $1.22 \pm 0.32^{\mathrm{b}}$ & $<0.05$ \\
\hline $\mathrm{PA}, \mathrm{g} \mathrm{kg}^{-1} \mathrm{KM}$ & & $4.96 \pm 0.39^{\mathrm{a}}$ & $3.82 \pm 0.84^{\mathrm{ab}}$ & $2.75 \pm 0.97^{\mathrm{bc}}$ & $1.57 \pm 0.25^{\mathrm{c}}$ & $<0.01$ \\
\hline $\mathrm{AA}, \mathrm{g} \mathrm{kg}^{-1} \mathrm{KM}$ & - & $13.10 \pm 3.20$ & $17.13 \pm 0.48$ & $18.54 \pm 3.17$ & $19.52 \pm 3.31$ & Ö.D \\
\hline KM Kaybı \% & - & $2.97 \pm 0.03^{\mathrm{a}}$ & $2.78 \pm 0.02^{\mathrm{b}}$ & $2.69 \pm 0.02^{\mathrm{c}}$ & $2.63 \pm 0.03^{\mathrm{d}}$ & $<0.001$ \\
\hline Flieg puanlaması & & $29.8 \pm 0.14^{\mathrm{c}}$ & $31.9 \pm 0.10^{\mathrm{b}}$ & $40.44 \pm 0.11^{\mathrm{b}}$ & $50.96 \pm 0.12^{\mathrm{a}}$ & $<0.01$ \\
\hline
\end{tabular}

Tk: Tampon kapasitesi, KM. Kuru madde, HP: Ham protein, $\mathrm{NH}_{3}-\mathrm{N}$ : Amonyağa bağlı nitrojen, SÇK: Suda çözünebilir

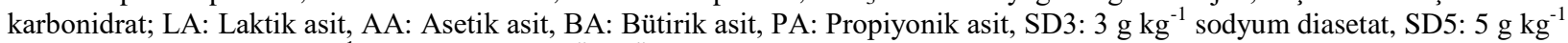
sodyum diasetat, SD7: $\mathrm{g} \mathrm{kg}^{-1}$ sodyum diasetat, ÖD: Önemli değil

Aynı satırda farklı harfle gösterilen ortalamalar arasındaki farklar önemlidir $(\mathrm{P}<0.05)$. 
Çizelge 2. Taze ve yonca silajlarının mikrobiyoloji analiz sonuçları $\left(\log _{10} \mathrm{kob} \mathrm{g}^{-1} \mathrm{KM}\right)$

\begin{tabular}{lccc}
\hline \multicolumn{1}{r}{ Muameleler } & LAB & Maya & Küf \\
\hline TM & 5.35 & 8.00 & 0,00 \\
Kontrol & $5.60 \pm 0.00^{\mathrm{d}}$ & $5.73 \pm 0.01^{\mathrm{c}}$ & $2.00 \pm 0.01^{\mathrm{a}}$ \\
SD3 & $5.68 \pm 0.02^{\mathrm{c}}$ & $5.78 \pm 0.10^{\mathrm{c}}$ & $0.00 \pm 0.00^{\mathrm{b}}$ \\
SD5 & $5.95 \pm 0.05^{\mathrm{b}}$ & $5.98 \pm 0.02^{\mathrm{c}}$ & $0.00 \pm 0.00^{\mathrm{b}}$ \\
SD7 & $6.12 \pm 0.05^{\mathrm{a}}$ & $6.16 \pm 0.04^{\mathrm{a}}$ & $0.00 \pm 0.00^{\mathrm{b}}$ \\
$P$ & $<0.001$ & $<0.001$ & $<0.001$ \\
\hline
\end{tabular}

Fermantasyonun 45. gününde açılan yonca silajlarına ait kimyasal analiz sonuçları Çizelge 1'de verilmiştir. Erken çiçeklenme döneminde hasat edilen yonca silajlarının $\mathrm{KM}$ içeriği $\% 23.3 \mathrm{~g} \mathrm{~kg}^{-1}$ iken 24 saatlik soldurma sonrasında \% 31.08 olmuştur. Fermantasyon 45. gününde KM içerikleri \% 28.0429.98 arasında değişmiştir. Çalışmada, fermantasyonun 45. gününde $\mathrm{SD} 5$ ve $\mathrm{SD} 7$ silajlarının $\mathrm{KM}$ düzeyinin kontrol grubu silajlara göre daha yüksek olduğu belirlenmiștir $(\mathrm{P}<0.05)$.

Silaj yapılacak kitlenin kapatılması sonrasinda da proteinlerin bitkisel enzimler aracılığı ile parçalanma süreci devam etmektedir. Proteolitik aktivitenin boyutları ve bu bağlamda da protein yıkımı miktarı ortamdaki asidik koşullarla ilişkili olup, silolamanın başlangıcındaki kritik dönemde $\mathrm{pH}$ değerindeki düşüşün hızı önemli bir faktördür (Petterson, 1988; McDonald ve ark., 1991). Anaerobik fermantasyonun ilk aşamalarında, amaca uygun LA fermantasyonunun gelişebilmesi bakımından önem taşıyan taze materyalinin $\mathrm{pH}$ 'sındaki değişimlerin yanı sıra, son ürünün sahip olduğu $\mathrm{pH}$ değeri de silaj $\mathrm{KM}$ tüketimi üzerinde önemli etkilere sahiptir. Çalışmada, yoncaya SDA ilave edilmesi silajların $\mathrm{pH}$ 'larını kontrol grubuna göre önemli düzeyde düşürmüştür $(\mathrm{P}<0.01)$. İyi kaliteli bir silajda $\mathrm{pH}^{\prime}$ nın 3.5-4.0 olması istenmektedir, fakat baklagil silajlarında 4.0 ve üzerindeki $\mathrm{pH}$ değerlerine çok sık rastlanmaktadır (Filya, 2001). Bu çalışmada, SDA ilave edilmesi silajların asitlik düzeyinin artmasına yol açmışsa da, fermantasyonun 45. gününde arzulanan $\mathrm{pH}$ düzeyine ulaşılamamıştır. Silajların başlangıç materyalinde 7.80 olan $\mathrm{pH}$ değeri fermantasyon dönemi sonunda, muamele gruplarında 5.80-5.35 arasında değişim göstermiştir.

Sodyum diasetat ilavesi HP içeriğinin artmasına sebep olurken $(\mathrm{P}<0.001)$, toplam nitrojen içerisindeki $\mathrm{NH}_{3}-\mathrm{N}$ miktarının düşmesini $(\mathrm{P}<0.001)$ sağlamıștır. Amonyağa bağlı nitrojenin, toplam nitrojene oranı $111.98-142.16 \mathrm{~g} \mathrm{~kg}^{-1} \mathrm{TN}$ arasında değişmiştir. En düşük $\mathrm{NH}_{3}-\mathrm{N}$ miktarı $7 \mathrm{~g} \mathrm{~kg}^{-1}$ SDA ilavesiyle sağlanmıştır. Kaliteli bir silaj için $\mathrm{NH}_{3}-\mathrm{N}$ miktarının $100 \mathrm{~g} \mathrm{~kg}^{-1} \mathrm{TN}$ düzeyinin altında olması gerektiği bildirilmektedir (McDonald ve ark., 1991). Silajlarda $\mathrm{NH}_{3}-\mathrm{N}$ değeri protein parçalanımının bir göstergesi olarak kabul edilmektedir. Bu çalışmada SDA ilavesi silajların $\mathrm{NH}_{3}-$ $\mathrm{N}$ değerlerinin kontrol grubuna göre düşmesine yol açmış, proteolizi önlemiştir.
Suda çözünebilir karbonhidrat içerikleri kontrol, SD3, SD5 ve SD7 gruplarında sirasiyla $9.96 \mathrm{~g} \mathrm{~kg}^{-1}, 8.72$ $\mathrm{g} \mathrm{kg}^{-1}, 8.00 \mathrm{~g} \mathrm{~kg}^{-1}$ ve $6.60 \mathrm{~g} \mathrm{~kg}^{-1} \mathrm{KM}$ olarak bulunmuştur. SÇK içeriği bakımından ise muameleler arasında istatiksel anlamda bir fark bulunmamıştır $(\mathrm{P}>0.05)$. Bu konuda yapılan benzer çalışmalarda artan SDA ilavesine bağlı olarak SÇK miktarının arttığı belirlenmiştir. Araştırıcılar bu artışı antifungal özelliğe sahip katk1 maddelerinin istenmeyen mikroorganizma gelişimini önleyerek KM ve kayıplarını azaltmasına bağlamaktadır (Nadeau ve ark., 2000; Da Silva ve ark., 2015; Wen ve ark., 2017; Yuan ve ark., 2017). Bu çalışmada ise artan SDA ilavesine bağlı olarak silajların SÇK içerikleri azalmıştır. Araştırmadaki başlangıç materyalinin SÇK içeriğinin ve KM miktarını artırmak amacı ile soldurma işleminin yapılması bu farklıllğa sebep olmuş olabilir.

En yüksek LA içeriği (70.04 $\left.\mathrm{g} \mathrm{kg}^{-1} \mathrm{KM}\right)$ SD7 grubunda, en düşük LA içeriği (6.77 $\left.\mathrm{g} \mathrm{kg}^{-1} \mathrm{KM}\right)$ ise kontrol grubunda belirlenmiştir. Yonca silajlarına SDA ilavesi silajların LA içeriklerini önemli düzeyde arttırmıştır $(\mathrm{P}<0.001)$. En yüksek AA içeriği $(19.52 \mathrm{~g}$ $\mathrm{kg}^{-1} \mathrm{KM}$ ) SD7 grubunda, en düşük AA içeriği (13.10 g $\mathrm{kg}^{-1} \mathrm{KM}$ ) ise kontrol grubunda olarak belirlenmiştir. AA içeriği bakımından muameleler arasındaki farklılıkların önemli olmadığı görülmüştür $(\mathrm{P}>0.05)$. Wen ve ark. (2017), yonca silajlarına katkı maddesi (formik asit, potasyum diformat, SDA ve kalsiyum propiyonat) ilavesinin fermantasyon ve mikrobiyal kompozisyon üzerine olan etkilerini inceledikleri bir çalışmada 30 günlük silolama periyodu sonrasında en yüksek LA ve AA içeriğini SDA grubunda tespit etmişlerdir. Araştırıcılar, SDA'nın LA ve AA içeriği üzerindeki artırıc1 etkisinin asidifikasyon ve antimikrobiyal özelliğinden kaynaklanabileceğini belirtmişlerdir.

Yonca silajlarının KM kaybı \% 2.63-2.97 arasında değişmiş ve yonca silajlarında artan SDA oranına bağlı olarak KM kaybı kontrol grubu silajlarına oranla daha düşük tespit edilmiştir $(\mathrm{P}<0.001)$. Silolamanın temel amaçlarından biri silolanacak materyaldeki KM kayıplarını mümkün olduğu kadar minimum düzeye indirmektir.

Ancak silaj fermantasyonunun homofermantatif veya heterofermantatif yönde şekillenmesine göre KM kayıpları artabilmektedir. Nitekim, fermantasyonun heterofermantatif bakteriler tarafından desteklendiğinde $\mathrm{CO}_{2}$ nedeniyle bu kayıplarda artış olabilmektedir (McDonald ve ark., 1991). Bu çalışmadaki veriler 
değerlendirildiğinde fermantasyonun heterofermantatif özellikte geliştiğini söyleyebiliriz. Goeser ve ark. (2015), yaptıkları araştırmada KM kaybı ve AA arasında pozitif yönde doğrusal bir ilişki olduğunu tespit etmişlerdir. $\mathrm{Bu}$ araştırmada benzer bir sonuca ulaşılmıştır, SDA miktarındaki artışa paralel olarak silajların AA içeriği artarken KM kaybı ise azalmıştır.

Yonca silajlarının PA içerikleri kontrol, SD3, SD5 ve SD7 gruplarında sirasiyla $4.96,3.82,2.75$ ve $1.57 \mathrm{~g}$ $\mathrm{kg}^{-1} \mathrm{KM}$ olarak bulunmuştur. Muamele gruplarının PA içeriği kontrol grubundan daha düşük bulunmuştur $(\mathrm{P}<0.01)$. Yonca silajlarının BA içerikleri 1.22-1.92 g $\mathrm{kg}^{-1} \mathrm{KM}$ arasında değişmiştir. Yonca silajlarında artan SDA oranına bağlı olarak silajların BA içerikleri kontrol grubu silajlara oranla daha düşük tespit edilmiştir $(\mathrm{P}<0.05)$. Silajlarda $\mathrm{BA}$ varlığ $\mathrm{c}_{\text {costridial aktivitenin }}$ ana ürünü olarak değerlendirilir. Silajlarda bulunan clostridiumlar aside karşı duyarlı mikroorganizmalardır. Silaj pH'sının 4.5 altında olduğu koşullarda gelişemezler (Saarisalo ve ark., 2007). Bu araştırmada clostridial aktiviteye bakılmamakla birlikte, fermantasyon sonrası silajların $\mathrm{pH}$ değerlerinin 4.5 üzerinde olması BA oluşumu ile ilgili bu görüşü destekler niteliktedir. $\mathrm{Bu}$ konuda yapılan benzer bir çalışma kontrol ve SDA ilave edilmiş gruplarda PA içeriklerini sırasıyla 2.91, 2.88, $2.74,2.56$ ve $2.34 \mathrm{~g} \mathrm{~kg}^{-1} \mathrm{KM}$, BA içeriklerini $1.59,1.71$, $1.66,1.48$ ve $1.53 \mathrm{~g} \mathrm{~kg}^{-1} \mathrm{KM}$ olarak bildirmişlerdir (Yuan ve ark., 2016). Araştırma sonuçları dikkate alındığında silajların PA düzeylerinin daha yüksek, BA düzeylerinin ise benzer olduğu söylenebilir.

Bu çalışmada, Flieg puanları kontrol, SD3, SD5 ve SD7 gruplarında sirasiyla $29.8,31.9,40.44$ ve 50.96 olarak hesaplanmıştır. Yonca silajlarında artan SDA oranına bağlı olarak silajların, Flieg puanları kontrol grubu silajlara oranla yükselmiştir, ancak sadece SD7 grubundaki silajlar orta kalite olarak değerlendirilmiştir $(\mathrm{P}<0.01)$.

\subsection{Yonca silajlarının mikrobiyolojik özellikleri}

Yonca silajlarının mikrobiyolojik analiz sonuçları Çizelge 3'de verilmiştir. Silajlarda Lactobacilli sayısı başlangıç materyaline oranla SDA ilavesiyle artmıştır. Lactobacilli say1s1 kontrol, SD3, SD5 ve SD7 gruplarında sirasiyla $5.60,5.68,5.95$ ve $6.12 \log _{10}$ kob $\mathrm{g}^{-1}$ olarak tespit edilmiştir $(\mathrm{P}<0.001)$.

Yonca silajlarında SDA uygulamasına bağlı olarak silajların maya sayıları artış göstermiştir. En yüksek maya sayıs1 $6.16 \log _{10} \mathrm{kob} \mathrm{g}^{-1}$ olarak SD7 grubunda tespit edilmiştir $(\mathrm{P}<0.001)$. Bu konuda yapılan benzer çalışmalarda da SDA ilave edilmiş silajların Lactobacilli ve maya sayıları kontrol grubuna göre daha yüksek tespit edilmiştir (Yuan ve ark., 2016). Kızılşimşek ve ark. (2016) fermantasyon süresi ilerledikçe maya sayılarında önemli azalmalar görülebildiğini, silajın fermantasyon döneminde mayaların varlığını sürdürmesinin anaerobik şartların devamlılı̆̆ına, silajın $\mathrm{pH}$ değerine, organik asitlerin yoğunluğuna ve maya türüne bağlı olarak değiştiğini bildirmektedirler. Nitekim taze materyal ile karşılaştırıldığında fermantasyon süresince tüm silajların maya sayılarında azalma gözlenmiştir.

Yonca silajlarında sadece kontrol grubunda 2.00 $\log _{10} \mathrm{kob} / \mathrm{g}$ düzeyinde küf tespit edilmiştir. Silo ortamında küflerin üremesi istenmez (Filya 2001. Çalışmada, kullanılan SDA antifungal bir etki göstermiş ve silajlarda küf gelişimine engel olmuştur.

\subsection{Yonca silajlarında aerobik stabiliteye ilişkin değerler}

Araştırmada, silolamanın 45. günü açılan yonca silajlarına uygulanan 7 günlük aerobik stabilite testi sonuçları Çizelge 4'de verilmiştir. Aerobik stabilitenin 7. gününde $\mathrm{KM}$ içerikleri kontrol, SD3, SD5 ve SD7 gruplarında sirasiyla $\% 30.21,30.52,28.81$ ve $\% 32.62$ olarak bulunmuştur. Yonca silajlarına SDA ilave edilmesi KM kaybını önlemiştir $(\mathrm{P}<0.001)$.

Yonca silajlarında aerobik stabilitenin 7. gününde kontrol, SD3, SD5 ve SD7 gruplarında belirlenen $\mathrm{pH}$ değerleri sirasıly $6.45,6.40,6.00$ ve 5.55 olarak bulunmuştur. Ancak SDA ilavesi aerobik dönemde $\mathrm{pH}$ değeri üzerine istatistiki anlamda herhangi bir etkisi olmamıştır $(\mathrm{P}>0.05)$. Söz konusu dönemlerde belirlenen $\mathrm{CO}_{2}$ üretim miktarları ise gruplarda sirasiyla 43.25, $23.51,21.73$ ve $16.12 \mathrm{~g} \mathrm{~kg}^{-1} \mathrm{KM}$ 'dir. Yonca silajlarına SDA ilave edilmesi $\mathrm{CO}_{2}$ üretimini düşürmüştür $(\mathrm{P}<0.001)$. Aerobik dönemde mayaların silajlarda oluşan LA ve kullanılmayan SÇK'ın fermente edilerek $\mathrm{CO}_{2}$ üretimine yol açtığı bildirilmektedir (McDonald, 1991). Nitekim araştırmada maya sayıları ile $\mathrm{CO}_{2}$ üretimleri paralellik göstermiştir. Yonca silajlarına SDA ilave edilmesi maya ve küf içeriklerini önemli ölçüde düşürmüştür $(\mathrm{P}<0.001)$.

Çalışmada 16SrRNA dizi analizi sonuçları değerlendirildiğinde, fermantasyon dönemi (45. gün) silajlarda LAB'inden Enterococcus faecium ağırlıklı olmak üzere, Lactobacillus brevis ve Pediococcus pentosaceu baskın türler olarak belirlenmiştir (Çizelge 4). Aerobik stabilite dönemi sonrasında ise ağırlıklı olarak Weissella paramesenteroides, Bacillus cereus, Bacillus sp. ve Bacillus megaterium türleri tespit edilmiştir. Araştırıcılar, silajlarda en çok rastlanan LAB türleri olarak Lactobacillus ve Streptococcus cinslerine ait türleri bildirmektedir. Silajda Lactobacillus plantarum, Enterococcus faecium, Lactobacillus brevis veya Lactobacillus buchneri gibi anaerobik LAB'nin etkin olması istenirken, Clostridia, Enterobactericiae, Bacilli ve Listeria gibi bakterilerin ise bulunmamas1 istenmektedir. $\mathrm{Bu}$ tür bakteriler, silaj kalitesinin düşmesine ve dolayısıyla da aerobik stabilitenin azalmasina neden olmaktadırlar (Pitt, 1986; Basmacığlu ve Ergül, 2002; Danner ve ark., 2003). 
Çizelge 3. Yonca silajlarının aerobik stabilite analiz sonuçları

\begin{tabular}{lcccccc}
\hline & $\mathrm{KM}^{1}$ & $\mathrm{pH}$ & $\mathrm{CO}_{2}{ }^{2}$ & Maya $^{3}$ & Küf $^{3}$ & Görsel Küflenme $^{4}$ \\
\hline Kontrol & $28.81 \pm 0.50^{\mathrm{c}}$ & $6.45 \pm 0.85$ & $43.25 \pm 1.11^{\mathrm{a}}$ & $6.89 \pm 0.00^{\mathrm{a}}$ & $6.62 \pm 0.00^{\mathrm{a}}$ & 4 \\
SD3 & $30.52 \pm 0.39^{\mathrm{b}}$ & $6.40 \pm 0.30$ & $23.51 \pm 0.48^{\mathrm{b}}$ & $6.80 \pm 0.04^{\mathrm{b}}$ & $0.00 \pm 0.00^{\mathrm{b}}$ & 1 \\
SD5 & $30.21 \pm 0.11^{\mathrm{b}}$ & $6.00 \pm 0.10$ & $21.73 \pm 0.73^{\mathrm{b}}$ & $6.69 \pm 0.03^{\mathrm{c}}$ & $0.00 \pm 0.00^{\mathrm{b}}$ & 1 \\
SD7 & $32.62 \pm 0.99^{\mathrm{a}}$ & $5.55 \pm 0.15$ & $16.12 \pm 1.57^{\mathrm{c}}$ & $6.38 \pm 0.08^{\mathrm{d}}$ & $0.00 \pm 0.00^{\mathrm{b}}$ & 1 \\
\hline$P$ & $<0.001$ & Ö.D & $<0.001$ & $<0.001$ & $<0.001$ &
\end{tabular}

${ }^{1} \mathrm{KM}, \%,{ }^{2} \mathrm{CO}_{2} \mathrm{~g} \mathrm{~kg}^{-1} \mathrm{KM},{ }^{3} \log _{10} \mathrm{kob} \mathrm{g}^{-1} \mathrm{KM}$, SD3: $3 \mathrm{~g} \mathrm{~kg}^{-1}$ sodyum diasetat, SD5: $5 \mathrm{~g} \mathrm{~kg}^{-1}$ sodyum diasetat, SD7: $7 \mathrm{~g} \mathrm{~kg}^{-1}$ sodyum diasetat, ÖD: Önemli değil

Aynı sütunda farklı harfle gösterilen ortalamalar arasındaki farklar önemlidir $(P<0.05)$.

${ }^{4}$ Silajlarda küflenme durumlarını görsel olarak 1'den 5'e kadar olan sayılarla değerlendirilmesidir. 1: hiç küf içermeyen bir silaj. 2: noktalar halinde çok az düzeyde küf içeren bir silaj. 3: noktalar halinde yüzeye yayılmış bir şekilde küf içeren bir silaj. 4: yüzeyi kısmen küf ile kapl, bölge bölge küflenmiş yüzeyleri olan silaj. 5: yüzeyi tamamen küf ile kapl, ağır bir kokuya sahip ve partikülleri birbirine yapışmış bir silaj. Bu değerlendirmeler üç kişi tarafindan yapılmakta ve daha sonra üçünün ortalaması alınmaktadır.

Çizelge 4. İzole Edilen LAB'lerinin 16SrRNA Dizi Analizi sonuçları

\begin{tabular}{ccc}
\hline Muameleler & 45. gün & AS \\
\hline Kontrol & Lactobacillus brevis & Weissella paramesenteroides \\
SD 3 & Pediococcus pentosaceus & Bacillus cereus \\
SD 5 & Enterococcus faecium & Bacillus sp. \\
SD 7 & Enterococcus faecium & Bacillus megaterium \\
\hline
\end{tabular}

SD3: $3 \mathrm{~g} \mathrm{~kg}^{-1}$ sodyum diasetat, SD5: $5 \mathrm{~g} \mathrm{~kg}^{-1}$ sodyum diasetat, SD7: $7 \mathrm{~g} \mathrm{~kg}^{-1}$ sodyum diasetat, AS: aerobik stabilite

Silaj fermantasyon dönemi sırasında ve aerobik stabilite sürecinde, farklı bakteri türleri farklı zamanlarda dominant duruma geçmektedirler. Mevcut araştırmadan elde edilen veriler fermantasyon dönemi ve aerobik stabilite dönemi sonrasında baskın olan türlerin farklılık gösterdiğini ortaya koymuştur.

\section{Sonuç}

Günümüzde, silaj katkı maddesi olarak kullanılan asitlerin olumlu etkilerinin yanı sıra, silaj ekipmanları üzerine olan çürütücü etkileri bu asitlerin tuzlarının kullanılmasına olan ilgiyi arttırmıştır. Araştırmada kullanılan SDA doz artışına paralel olarak, yonca silajlarının fermantasyon özelliklerini aerobik stabilitesini olumlu yönde etkilemiştir. Çalışmada, SDA antibakteriyal etki göstererek yonca silajlarında zararlı mikroorganizma (maya ve küf) sayılarını düşürmüş ve aynı zamanda Lactobacilli sayılarını ve etkinliğini arttırmıştır. Buna bağlı olarak şekerlerin LA'e dönüşümü artmış ortamda yüksek oranda bulunan LA, pH'yı düşürerek proteinleri parçalayan enzimleri inhibe etmiş ve proteinlerin amonyağa parçalanma oranını düşürmüştür.

Çalışma sonucunda elde edilen veriler özellikle yağışların bol olduğu ve kurutma imkanının olmadığg dönemlerde yoncanın SDA ilave edilerek silolanmasının fermantasyon özelliklerini ve aerobik stabiliteyi iyileştirdiğgini ve en etkili dozun $7 \mathrm{~g} \mathrm{~kg}^{-1}$ olduğunu ortaya koymuştur. Ancak, kullanım etkinliğini belirleyen faktörler göz önüne alındığında, yurdumuzun farklı ekolojilerinde farklı bitkisel materyallerden hazırlanan silajlarda, SDA dozu ile ilgili öneriler için laboratuvar ve saha koşullarında gerçekleştirilebilecek çalışmalara gereksinim duyulmaktadır.

\section{Teşekkür}

$\mathrm{Bu}$ çalışma, "Sodyum diesatat ilavesinin yonca silajlarının fermantasyon özellikleri ve aerobik stabilitesi üzerine etkileri” isimli yüksek lisans tez çalışmasından üretilmiştir.

\section{Kaynaklar}

Akyıldız, A.R., 1984. Yemler Bilgisi Laboratuar Kılavuzu. A.Ü. Zir. Fak., Ankara, Ankara Üniversitesi Basımevi, Uygulama Kılavuzu, $236 \mathrm{~s}$.

Altınçekiç, E., Filya, İ., 2018. Bakteriyal inokulant ve organik asit kullanımının düşük kuru maddeli küçük balya misır silajlarının aerobik stabilite ve yem değeri üzerine etkisi. Türk Tarım-Gıda Bilim ve Teknoloji Dergisi, 6 (7): 887-892.

Anonim, 1986. The Analysis of Agricultural Material, Reference Book: 427, 428 p, London.

Ashbell, G., Weinberg, Z.G., Azrieli, A., Hen, Y., Horev, B., 1991. A simple system to determine the aerobic determination of silages. Can. Agric. Eng. 33: 391-395. 
Basmacıoğlu, H., Ergül, M., 2002. Silaj mikrobiyolojisi. Hayvansal Üretim Dergisi 43(1): 12-24.

Boyacı Gündüz, C.P., 2018. Nohut mayası ve ekşi hamur fermantasyonlarındaki laktik asit bakterilerinin ve mayaların moleküler yöntemlerle tanımlanması ve bazı laktik asit bakterilerinin starter kültür olarak kullanılma potansiyellerinin araştırılması. Doktora tezi. Çukurova Üniversitesi Fen Bilimleri Enstitüsü.

Çerçi, İ.H., Şahin, K, Güler, T., 1996. Farklı oranlarda silajlık misır yonca kullanılarak yapılan silajların kalitesinin belirlenmesi. F. Ü. Sağ. Bil. Derg, 10 (2): 193-200.

Çiftçi, M, Çerçi, İ.H., Dalkılıç, B., Güler, T., Ertaş, O.N., 2005. Elmanın karbonhidrat kaynağı olarak yonca silajına katılma olanağının araştırılması. YYÜ Vet. Fak. Derg. 16 (2):93-98.

Da Silva, T.C., Smith, M.L., Barnard, A.M., Kung, Jr L., 2015. The effect of a chemical additive on the fermentation and aerobic stability of high-moisture corn. J. Dairy Sci. 98, 8904-8912.

Danner, H., Holzer, M., Mayrhuber, E., Braun, R., 2003. Acetic acid increases stability of silage under aerobic conditions. Applied and Environmental Microbiology, Vol 69 (1), p. 562-567.

Efe, E., Bek, Y., Şahin, M. 2000. SPSS’te çözümleri ile istatistik yöntemler II. Kahramanmaraş Sütçü İmam Üniversitesi Rektörlüğü Yayınları, Kahramanmaraş, 223s.

Filya, İ., Ashbell, G., Hen, Y., Weinberg, Z.G., 2000. The effect of bacterial inoculants on the fermantation and aerobic stability of whole crop wheat silage. Animal Feed Sci. Technology, 88:39.

Filya, İ., 2001. Silaj Teknolojisi. Uludağ Üniversitesi Ziraat Fakültesi Zootekni Bölümü, 16059, Görükle, Bursa.

Goeser, J.P., Heuer, C.R., Crump, P.M., 2015. Forage fermentation product measures are related to dry matter loss through meta-analysis. Prof. Anim. Sci. 31, 137-145.

Güler, T., 2001. Silaj ve hayvan beslemede kullanımı. Konferanslar. F.Ü. Vet. Fak. Elazığ. 27-36.

İpçak, H.H., Özüretmen, S., Özelçam, H., Ünlü, H.B., 2017. Hayvan beslemede antibiyotiklere alternatif olarak organik asit, esansiyel yağ ve bakteriyosinlerin kullanımı. Hayvansal Üretim 58(1): 57-65.

Kılıç, A., 1986. Silo yemi. Bilgehan Basımevi Bornova İzmir. 1986. 68-72.

Kızılşimşek, M, Erol, A., Ertekin, İ., Dönmez, R., Katranc1, B., 2016. Silaj mikro florasının birbirleriyle ilişkileri, silaj fermentasyonu ve kalitesi üzerine etkileri. KSÜ Doğa Bil. Derg., 19 (2), 136140 .
Kleinschmit, D.H., Schmidt R.J., Kung, L., 2005. The effects of various antifungal additives on the fermentation and aerobic stability of corn silage. J. Dairy Sci. 88:2130-2139.

Koç, F., Coşkuntuna, L., 2003. Silo yemlerinde organik asit belirlemede iki farklı metodun karşılaştırılması. Journal of Animal Production. 44(2): 37-47.

McDonald, P., Henderson, A.R., Heron, S.J.E., 1991. The Biochemistry of Silage. Second Edition. 340 p., Chalcombe Publication, Marlow, England.

Nadeau, E.M.G., Buxton, D.R., Russell, J.R., Allison. M.J, Young, J.W., 2000. Enzyme, bacterial inoculant, and formic acid effects on silage composition of orchardgrass and alfalfa. J. Dairy Sci. 83, 1487-1502.

Petterson, K., 1988. Ensiling of forages: Factors affecting silage fermantation and quality, Sveriges Lantbruksuniversitet, 46 p, Uppsala, Sweden.

Pitt, R., 1986. Microbial and enzymatic additives for ensiling. 54th, (pp. 137-147). Cornell Nutrition Conference for Feed Manufacturers. Proc Cornell Nutr Conf Feed Manuf 199.

Playne, M.J, McDonald, P., 1966. The buffering constituent of herbage and of silage, J. Sci. Food. Agric, 17:264-268.

Seale, D.R., Pahlow, G., Spoelstra, S.F., Lindgren, S., Dellaglio, F., Lowe, J.F., 1990. Methods for the microbiological analysis of silage. Proceeding of the Eurobac Conference, 147, Uppsala.

Settanni, L., Tanguler, H., Moschetti, G., Reale, S., Gargano, V., Erten, H., 2011. Evolution of fermenting microbiota in tarhana produced under controlled technological conditions, Food Microbiol. 28, 1367-1373.http://garfield.library.upenn.edu/ classics1977/A1977DM04100001.pdf

SPSS Inc., 2007. SPSS for Windows, Version 16.0. Chicago, SPSS Inc.

Supelco, 1998. Analyzing fatty acids by packed column gas chromatography, Sigma-Aldrich Corp, Bulletin 856, Bellefonte, PA.

Wen, A.Y., Yuan, X.J., Wang, J., Desta, S.T., Shao, T., 2017. Effects of four short-chain fatty acids or salts on dynamics of fermantation and microbial characteristics of alfalfa silage. Animal Feed Science Technology. 223: 141-148.

Yuan, X.J., Wen, A.Y., Desta, S.T., Wang, J., Shao, T., 2017. Effects of sodium diacetate on the fermentation profile, chemical composition and aerobic stability of alfalfa silage. Asian-Australas J Anim Sci 30: 804-810.

Yuan, X.J., Wen, A.Y., Wang, J., Desta, S.T., Dong, Z.H., Shao, T., 2016. Effects of four short-chain fatty acids or salts on fermentation characteristics and aerobic stability of alfalfa (Medicago sativa L.) silage. J.Sci Food Agric; 98: 328-335. 